\title{
Risks of Development and Implementation of Innovative Projects
}

\author{
Aleksandr Mihajlovich Batkovskiy ${ }^{1}$ \\ Alina Valerevna Konovalova² \\ Elena Georgievna Semenova ${ }^{3}$ \\ Valerij Yaroslavovich Trofimets ${ }^{2}$ \\ Alena Vladimirovna Fomina ${ }^{1}$ \\ 1 Joint Stock Company "Central Research Institute of Economy, Management and Information Systems "Electronics", \\ Moscow, Russian Federation \\ 2Department of Economic Analysis and Informatics, P.G. Demidov Yaroslavl State University, Yaroslavl, Russian Federation \\ ${ }^{3}$ The Department of Innovation and Quality Management, St. Petersburg State University of \\ Aerospace Instrumentation, St. Petersburg, Russian Federation \\ Email: batkovskiy_a@instel.ru
}

Doi:10.5901/mjss.2015.v6n4s4p243

\begin{abstract}
Project-based approach is one of the most widespread approaches to promotion of innovations. Risk management in innovative projects is one of the most difficult tasks in project management due to high degree of uncertainty which is intrinsic to innovative projects. Depending on the phase of innovation's life cycle, the parameters of innovative projects' risk management change, which, in turn, results in the need to use various methodic tools. The key risks on the phase of development and implementation of an innovative project include the risk of non-realizability of an innovative idea and the group of risks related to failure to achieve the basic project parameters including the timing risk, project budget deficit risk and the risk of failure to achieve the innovation's targets. Targets include improvement in risk management on the phases of development and innovations in case of the project-based approach through development and adaptation of existing and elaboration of new approaches and methods of risks identification, assessment and mitigation. This article solved the following issues, which contribute to achievement of the above goal: - identification of key risks of innovative projects, which are intrinsic to the phases of project development and implementation; - adaptation, enhancement and development of methodical tools for assessment and analysis of the key risks of innovative projects; - elaboration of enforcement actions focusing on the key risks of innovative projects on the basis of data obtained in the course of risk assessment. The research allowed to develop the algorithm of innovative projects' risk management on development and implementation phases, which implies consistent and systematic realization of management stages and matching of assessment results with the risk treatment steps, taking into account the innovative nature of projects.
\end{abstract}

Keywords: innovative project, phases, development and implementation, risk, timeframe, budget, analysis.

\section{Introduction}

Transition from the export- and commodity-based model to the innovative development model is the key aspect of largescale transformations in the Russian economy. In this respect, innovations are considered as not just one of the phenomena which affect the economic growth and structural shifts in the national economy - they should become the principal factor leading to quality changes in the business environment within economic systems.

Project-based approach is one of the most widespread approaches to promotion of innovations. Such approach provides for development of a project, within which a set of interrelated tasks is solved: project's subject matter management, management of the project quality, timing and cost, risk management, efficiency management, team management and communication management.

The task of innovative projects' risk management is one of the most difficult in project management due to significant degree of uncertainty regarding future result. Depending on the phase of innovation's life cycle, the parameters of innovation projects' risks management change, which, in turn, results in the need to use various methodic tools.

Risk management shows itself in development and implementation of measures focusing on mitigation of the risks' impact on the ultimate results of project implementation. Even if risk management is not formalized, risk managers agree 
that in case of a risk situation, first of all, it is necessary to single out the sources and factors of risk (risk identification), to assess the scale of consequences (risk assessment and measurement), to make decision on actions/omissions (elaboration of risk management measures) and to implement selected measures (realization of selected risk management method) (Kaplan, S., 1997).

\section{Literature Review}

Theoretical and methodological approaches to the study of specific features of innovative development were discussed by many economists. Modern issues of risk management were examined by Bernstein (Bernstein, P.L., 1996), Balabanov (Balabanov, I.T., 1996), Ivanov (Ivanov, A.A. et al., 2008) etc, and, particularly, specific features of risk management in respect of innovations in general and innovative projects in particular were formulated be Kulikova (Kulikova, E.E., 2008), Karzhaev (Karzhaev, A.T. ,2006), Popov (Popov, V.L., 2009), Vertakova and Simonenko (Vertakova, Ju.V. and Simonenko, E.S., 2008), Valdajcev (Valdajcev, S.V., 1997), Samovoleva (Samovoleva, S.A., 2008), Taplin and Schymyck (Ruth Taplin and Nick Schymyck, 2005), Shapira (Shapira, Z., 1995) Johnstone-Bryden (Johnstone-Bryden, I.M., 1996), Elahi (Elahi, E.,2013) et al.

The analyzed approaches to innovative projects' risk management have some weaknesses:

- the innovative projects' risk system, risk assessment and risk treatment methods directly depend on the area of innovations' application;

- $\quad$ on different phases of innovative project's implementation a set of risks and risk-generating factors, which, in turn, require different methodological tools of risk assessment and risks analysis (Marle, F. and Gidel, T., 2015);

- risks, as an economic category, are heterogeneous, having the dynamic nature; as a result, the structure of risks, as well as their impact on the project's key parameters may change in the course of time. Such key peculiarities of risks are enhanced by the degree of uncertainty intrinsic to innovative projects (Allen, Fr. and Gale, D., 1994);

- in terms of the analyzed approaches, risks are divided mainly only on the basis of risk objects, which results in consideration of risks of different degree of aggregation and different nature as equivalent;

- most risks identified by the authors are not subject to quantitative analysis with the use of mathematical models (e.g., a group of technical, technological, legal risks, force-majeure risks etc.)

- risk assessment methods described in the literature are discrete, and mechanical joining of commonly used methods of risk analysis and assessment suggested within the approaches under consideration is often impossible due to methodological separateness thereof;

- non-applicability of the probability theory based on the classic standard distribution for consideration of subjective (axiological) probabilities, intrinsic to innovation processes (Nedosekin, A.O. and Abdulaeva, Z.I., 2010). Starting from 1950s, some authors noted in their academic works that classical probability is axiomatically defined as a characteristic of a general population of statistically homogeneous casual events. In the absence of statistical homogeneity, application of classic probabilities in analysis becomes illegal. The fundamental works by Savage, Poy, Kayberg, Fishbern (Fishbern, P., 1978), de Finetti etc., where introduction of non-classic probabilities with frequencies that do not make sense (the so called 'subjective' ('axiological') probabilities) in respect of heterogeneous samples became the response to these entirely grounded remarks;

- some of the described risk assessment methods are unacceptable for innovative projects: e.g., the analog method;

- simultaneous use of a large quantity of assessment methods results in unreasonable increase in calculation efforts, as some methods are interchangeable in the above approaches. For example, expert assessment methods and professional judgment methods (Olsson, N.O.E. and Spjelkavik, l., 2015). At the same time, some authors use insufficient quantities of calculation methods for obtaining a broad picture of project implementation risks with the purpose of application of efficient and effective measures against risks (e.g. Valdajcev (Valdajcev, S.V., 2001) and Fathutdinov (Fathutdinov, R.A., 2003) approach). These methods should be applied pointwise and rely on data obtained in the course of quantitative risk analysis.

Hence, the task of formation of a single methodological approach to risk management in innovative projects is quite relevant (Bowers, J. and Khorakian, A., 2014). The above difficulties and deficiencies of approaches to risk management in innovative projects pointed out to the need for development and enhancement of approaches to identification, assessment and mitigation of risks pertaining to innovative designs. 


\section{Methods}

From the formal perspective, risk is considered as a probability of occurrence of adverse conditions, which are related either to:

- failure to achieve the expected results from innovations;

- deficit of planned resources.

Therefore, risk situations may be divided into four types (Gracheva, M.V. and Ljapina, S.V., 2010):

- the result was not achieved at all due to impossibility to implement an innovative idea;

- technical or economic characteristics of innovation turned out to be worse than the characteristics expected by the company's management;

- innovative project was implemented, but its costs exceeded the original budget;

- innovations' objective was achieved, but later than expected (Figure 1).

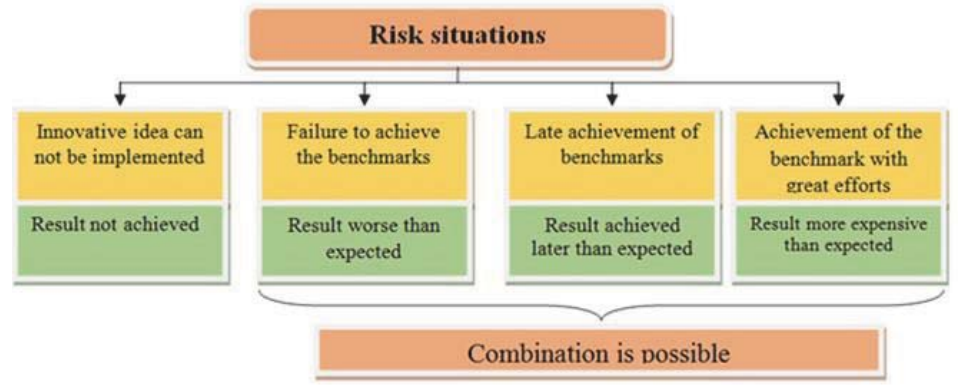

Figure 1. Risk situations

In the light of risk situations, the risks which may directly lead to suspension or termination of the project include the risks intrinsic to any innovative project. On the phases of development and implementation of an innovative project, such risks include: risk of non-realizability of an innovative idea, which is subject to the innovative nature of the project due to high degree of uncertainty in respect of future performance, risk of failure to achieve the planned functional characteristics of innovation, the timing risk and project's budget deficit risk. Impact of the above risks on project implementation is enhanced by the degree of innovativeness of the realized idea. On the phase of innovation's commercialization, marketing levers get involved; therefore, the key risks of this phase include the risk of failure to achieve the expected financial performance (income) and the risk of achievement of financial performance (income) with adverse deviations from expectations.

The above risks are complex, being initiated by individual or mixed impact of specific risks of a particular project, the impact of which is difficult to express in quantitative terms. Therefore, two levels of risks should be distinguished: first (upper) level risks include key risks of innovative projects related to occurrence of basic risk situations during project implementation (Figure 1), second (lower) level risks include innovative project-specific risks resulting in the launch of the mechanism of first level risks emergence.

Such organized system of innovative project risks allows to update the tasks which experience the strongest impact of hardly quantifiable specific risks and elaborate risk treatment measures in respect of the tasks through assessment of key risks (first of all, the timing risk and project budget deficit risk).

\subsection{Management of the timing risk}

It would be reasonable to start assessment of the timing risk with construction of the project's network diagram. The Critical Path Method reveals the tasks which belong to critical and non-critical path of the project and determines duration of this path (Eliyahu M. Goldratt., 1997).

Then, possible scenarios of project development are projected on the basis of the scenario-based approach with due account for the project task duration growth ratios specified by experts.

On the basis of obtained fluctuations in the project's phase duration, the timing risk is assessed using the Program/Project Evaluation and Review Technique. As stated above, the peculiarity of innovative project risk 
assessment lies in the shift of focus from determination of probabilities by beta distribution towards subjective (axiological) probabilities. Therefore, the improved formula for finding mathematical expectation of work (task) fulfillment time $m_{p}$ is suggested (Batkovskiy, A.M. et al., 2014):

$$
m_{p}=(Q+4 R+W) / 6 \text {, }
$$

where $m_{p}$ is the mathematical expectation of work fulfillment $p$;

$Q$ is the duration of task in case of optimistic scenario realization;

$R$ is the task duration according to the project's schedule;

$W$ is the task duration in case of pessimistic scenario realization.

The weights allocation suggests that the pessimistic scenario is more probable than the optimistic one, but not more probable than the actually scheduled time of task/project implementation; i.e., the "moderate pessimism" principle, which is the most widespread in respect of innovative projects implementation, is realized.

In this case, standard deviation $y_{p}$ of tasks or the entire project duration will be equal to (Klimenko, O.):

$$
\sigma_{p}=(W-Q) / 6
$$

The probability of task realization within the scheduled timeframe will be determined by the following formula:

$$
P=1-\frac{\sigma_{p}}{m_{p}}
$$

The data obtained in the course of PERT implementation lead to a conclusion regarding exposure of each task to fluctuations in durations, and, therefore, to the impact of specific risks and risk factors, and such data allow to project potential losses of time on project tasks.

Potential losses of time are determined by the suggested formula, which takes into account duration of task and the level of variability of the task fulfillment time subject to the impact of specific risks:

$$
T A R=\text { THOp }_{i} \cdot k_{1-\alpha i} \cdot \sigma p_{i},
$$

where TAR means expected losses of time for a project task;

THормі means task duration in accordance with the project's schedule;

$k_{1-6 i}$ means the quantile of the probability distribution;

$y p_{i}$ means the square deviation obtained in the course of PERT implementation.

Depending on the timing risk identification and assessment, risk treatment measures may be applied.

The author's approach implies estimation of the reserve for the project's most risky tasks. In such case, the risky tasks will include not only critical path tasks, but also the tasks, the timing failure of which may adversely affect the launch and fulfillment of the critical path tasks (and, therefore, the project schedule, in general).

A non-critical path task may adversely affect the project's timing when its duration is long enough to affect the project's schedule, and the task completion time is subject to large fluctuations. As a result, the float time of non-critical task may be insufficient for "insurance" of the start of the critical path task. So, the non-critical project path task is recognized as risky, if potential delay with task fulfillment exceeds the non-critical task's float time:

$$
\text { TAR }>\text { float }
$$

Time-At-Risk is affected by duration of the non-critical path task and the task's exposure to duration fluctuations. If the task duration is subject to significant fluctuations due to the impact of second level factors, but the float time covers the maximum possible fluctuation, such task is not dangerous for the project implementation.

With the project's time reserve or in the absence of expressly defined project completion date we may estimate the maximum allowable duration excess for each task. Buffers are allocated for critical chain tasks and for the tasks which are the most exposed to duration fluctuation with account for the percentage of potential excess of duration in the aggregate assumed delay of the phase/project and with account for the project's buffer amount or the time buffer between the project phases. The suggested formula for determination of safe increase in the task duration is as follows:

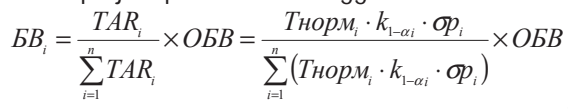

where $5 B_{i}$ means the reserve time (buffer) for $i^{\text {th }}$ project task;

$T A R_{i}$ means expected losses of time for $i^{\text {th }}$ project task;

Tнормі means task duration in accordance with the project's schedule;

$k_{1-6 i}$ means the quantile of the probability distribution for $i^{\text {th }}$ project task;

$y p_{i}$ means the square deviation obtained in the course of PERT implementation. 
OБB means the overall project time reserve (buffer).

The reserve shows the extension which the organization may afford without delaying the project completion time or start of further phases rather than the quantity of days of potential excess of the phase's timeframe.

If the project's time reserve for certain phases or the project in general is not planned, or if the estimated time reserve can not prevent fluctuations in the project completion time $(5 B<T A R)$, then tough deadlines may be achieved through the impact of dissipation on timing risks and specific project risks: distribution of risks among separate structural divisions of the organization. Dissipation may take the form of:

- involvement of specialists from related business units or branches which contributed to development and implementation of the innovative project in their subdivisions;

- creation of a specialized group of employees for implementation of the project in all structural subdivisions of the organization;

- sharing of experience among the specialists who developed and implemented the project.

Algorithm of project's timing risk mitigation is shown on Figure 2.

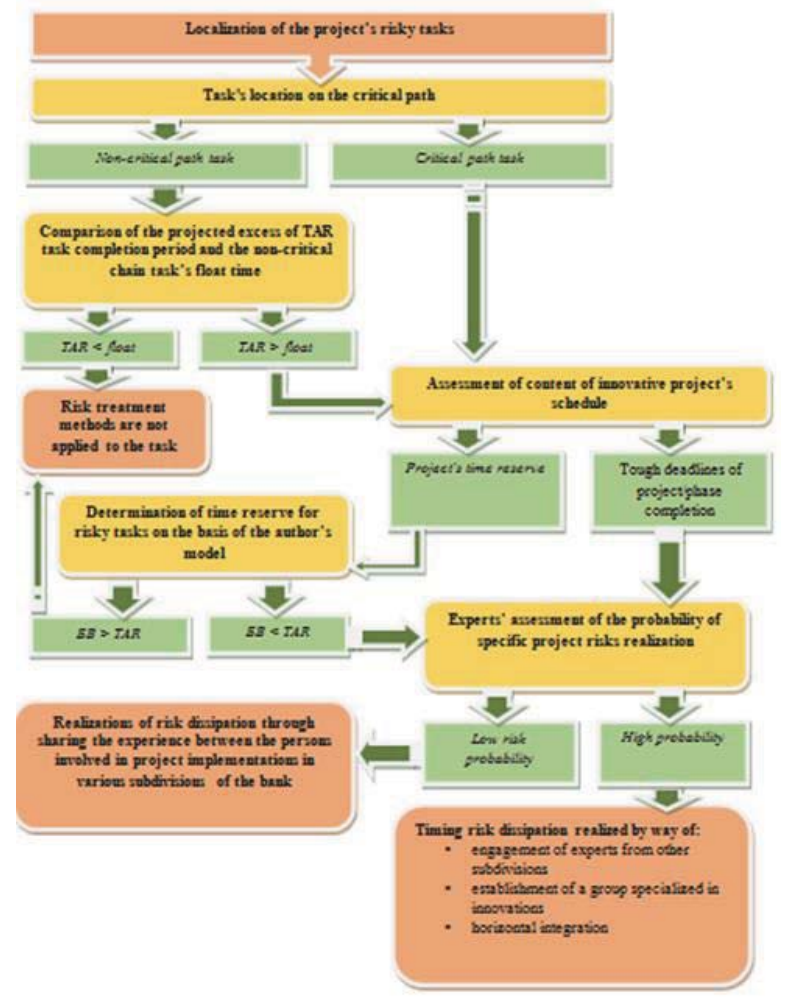

Figure 2. Algorithm of project's timing risk mitigation.

\subsection{Project's budget deficit risk management}

The procedure for assessment of the project's budget deficit risk is in many aspects the same as the procedure for assessment of the project timing risk, with certain specific features. If in case of estimation of time losses a certain task or phase of the project were considered as a risk management object, then in this case the object may be represented by a cost item (in accordance with the project budget) rather than the task.

Project budget deficit risk assessment procedure starts from generation of scenarios of fluctuations of the project task costs on the basis of combination of the scenario-based approach (with account for allowable and marginal growth ratios for certain tasks (or budget items) of the project, which are determined by experts) and the simulation-based 
stochastic model (geometrical Brownian movement model) (Demkin, I.V., 2005a):

$$
S_{t}-S_{t-1}=S_{t-1}(\mu \cdot \Delta t+\sigma \varepsilon \sqrt{\Delta t}),
$$

where $\Delta t$ means duration of the interval between neighboring object observations;

e means random noise represented in a form of a normalized normally distributed random variable;

$\mu, y$ mean the stochastic process parameters (mathematical expectation and volatility) assessed by using the regression analysis method.

Simultaneous application of the scenario-based method and simulation modeling allows to construct the data sample using subjective judgments and objective data of the stochastic modeling.

On the basis of obtained scenarios, the losses caused by the risk factors impact are assessed using VAR analysis. It should be noted that such characteristics as the value and time of project implementation are correlating factors. Fluctuations of the project duration increase the cost, primarily due to growth in daily labor costs. That's why, project duration scenarios should be taken into account for assessment of possible absolute losses.

So, for the tasks, which are independent from fluctuation of the project completion time, the basic formula of VAR analysis should be used:

$$
V A R=P_{t-1} e^{\mu-k_{1-\alpha} \sigma} \approx P_{t-1}\left(\mu-k_{1-\alpha} \sigma\right),
$$

where $P_{t-1}$ is the cost of the task in accordance with the project budget;

$\mu, y$ means mathematical expectation and mean square deviation of the task cost fluctuation, respectively, calculated by the indicators growth rate;

$k_{1-6}$ means the quantile of probability distribution,

and for the tasks subject to fluctuation of the project completion time, the basic formula of VAR analysis should be used with account for fluctuation in the project duration (Demkin, I.V., 2005b):

$$
V A R=P_{t-1}\left(\mu \frac{T}{t}-k_{1-\alpha} \sigma \sqrt{\frac{T}{t}}\right)
$$

where $T$ means duration of the task (project) in accordance with pessimistic forecast;

$t$ means duration of the task (project) in accordance with the calendar plan.

The project budget deficit risk is mitigated with the risk financing method on the basis of assessment of projected losses from the impact of risk factors, which result in excess of scheduled costs. The first stage should include determination of reservation objects - risks localization.

When determining the reserves, it is important to reduce the risk to an acceptable level, ensuring security of the project from fluctuations using the maximum amount of funds, which can be "frozen' by the organization (diverted from regular operations).

A project task or a project budget item may be used as the unit of reservation, subject to the nature of budget disclosure. The most successful (from the perspective of the project budget deficit risk management concept) is the phase-by-phase planning of budget amounts, as it provides for release of funds upon fulfillment of the project tasks, not requiring one-time diversion of a significant amount.

Transactions with the following parameters should be recognized as risky:

- being a part of a critical chain;

- $\quad$ high percentage of expenses for execution of transaction in total expenses for innovations (more than 5\%);

- high variability of expenses for execution of a transaction ( $\left.{ }^{\sigma p_{i}}>\sigma p_{\text {oöu }}\right)$.

If the budget's structural itemization provides for specification of cost items rather than the tasks, then the first selection criterion does not apply.

In such case, the task becomes an object of funds reservation, if its value exceeds $5 \%$ of the innovative project's budget. The project's task is admitted as a task with high variability of value, if its exposure to fluctuations is higher than the planned one:

$$
\sigma p_{i}>\sigma p_{\text {об̆ }}
$$

where $\sigma p_{i}$ means square deviation of $i^{\text {th }}$ task/cost item value;

$\sigma p_{\text {оби }}$ means square deviation of the project budget

The above estimated criteria should be met at the same time. If the task completion cost is exposed to significant fluctuations due to the impact of specific risks - second level risks, but the percentage in the budget is small, potential losses from completion of such tasks or expenses are admitted as insignificant, and the reserve does not have to be 
created.

According to the algorithm, localization is effected not only for critical path tasks, but also for the project tasks assessed as the most risky under the suggested criteria (Figure 3).

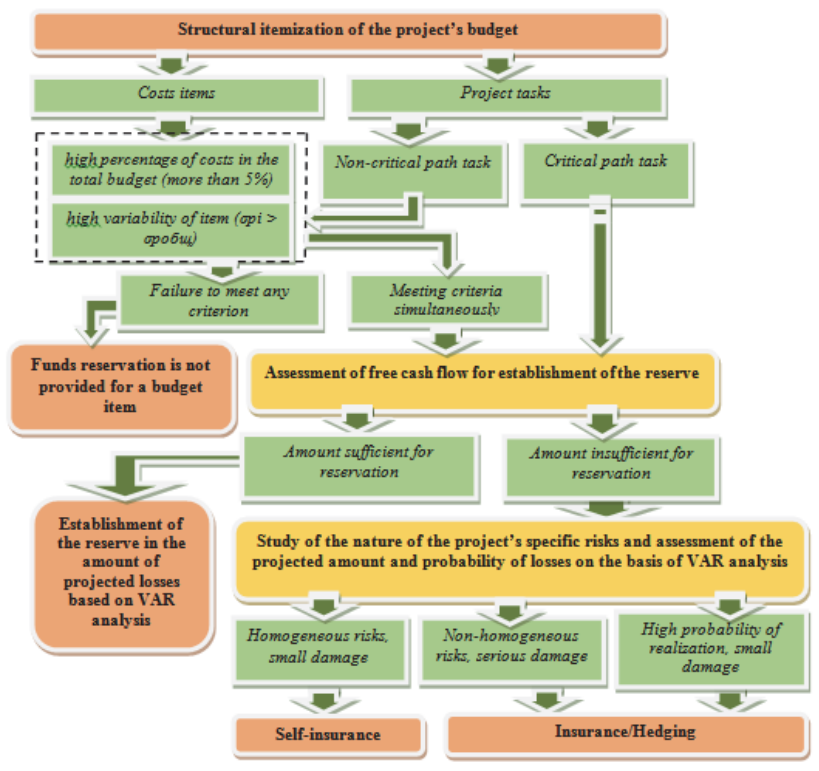

Figure 3. Algorithm of project budget deficit risk assessment

Reserve is established for specified tasks/cost items on the basis of projected losses obtained during VAR-analysis, with account for importance of selection of the projected damage coverage source. In case of insignificant projected losses and available free cash flow, organizations will form a reserve fund. If the amount of free cash flow is not sufficient for generation of reserves for the most risk-exposed tasks/budget items, then self-insurance, execution of an insurance agreement or hedge agreement (resulting in risk transfer) may be considered.

In case of risk realization, the organization will cover losses out of the reserved funds or insurance coverage. If preventive measures in respect of risk factors are not taken, the organization will cover the occurred losses out of its current income, or it may use the mechanism for raising additional funding, if losses are significant. The mechanism of selection of the financing method for possible losses is implemented in the management decision plan with impact on the project budget deficit risk (Figure 4).

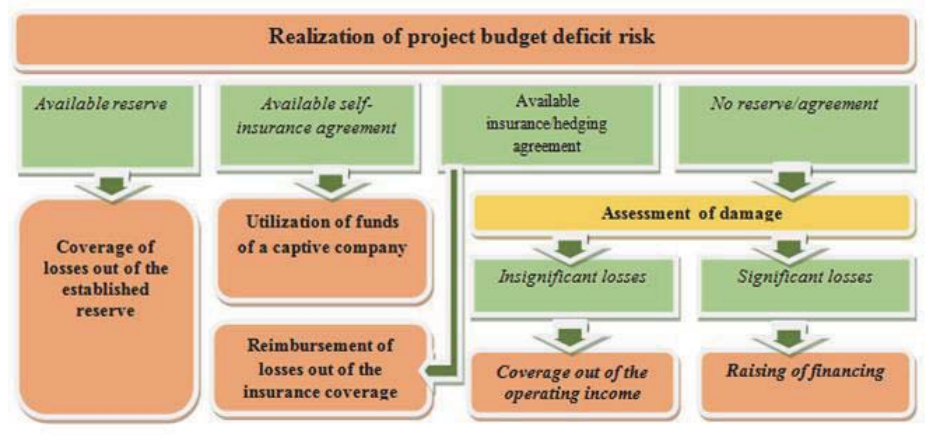

Figure 4. Algorithm of project budget deficit risk mitigation 


\section{Results}

Elaborated algorithms of key risks assessment and mitigation on the innovative project's realization and implementation phases - the timing risk and project budget deficit risk - may be combined into a single algorithm of innovative project risk management on development and implementation phases.

Risk identification is the first phase of the elaborated algorithm identification, which, first of all, is reduced to mapping of specific risks, the impact of which on the key risks of this phase (the timing risk and project budget deficit risk) is ambiguous and weakly formalized.

According to the risks determined on the second phase, algorithm paralleling in two directions (two branches) the timing risk and project budget deficit risk management - occurs.

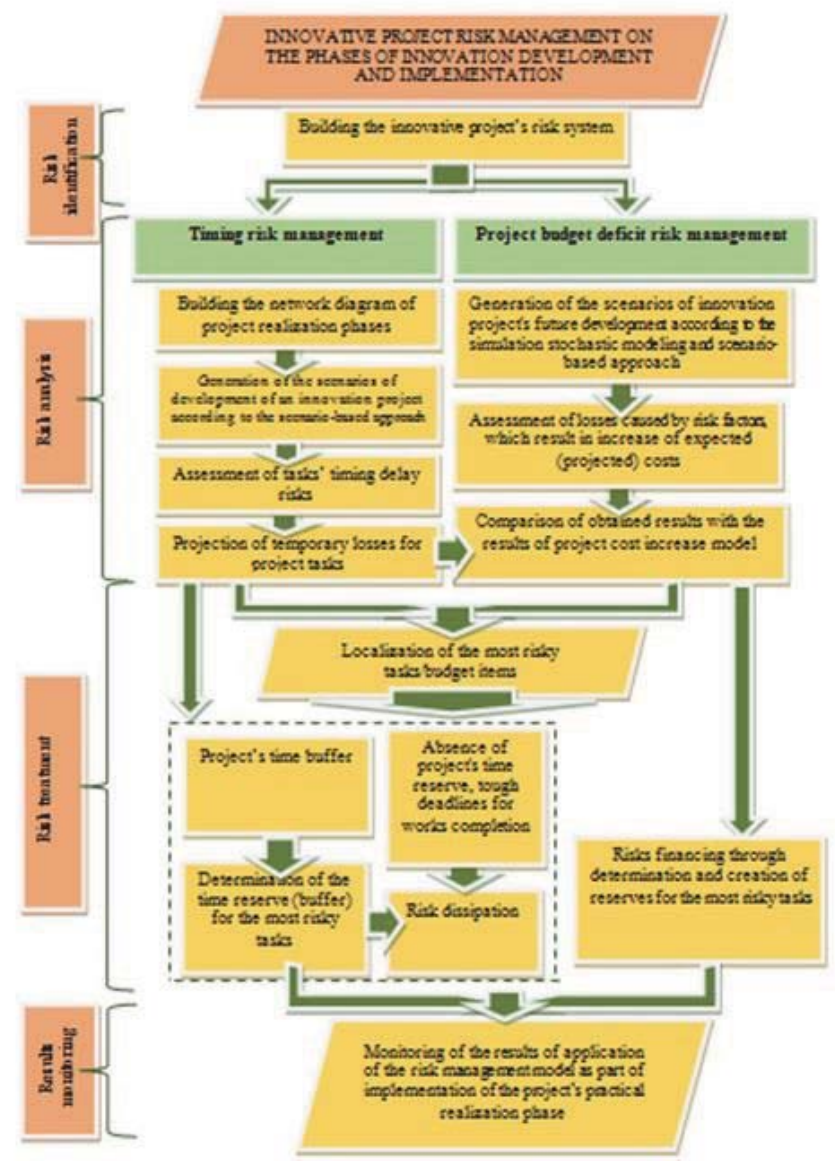

Figure 5. The algorithm of innovative project risk management on development and implementation phases

Assessment procedures focus on identification of possible adverse deviations in time and financial costs required for project tasks implementation. In order to assess the possibility of an adverse scenario and to determine costs, assessment procedures are used on the basis of combination of objective statistical methods and subjective expert judgments. Statistical methods allow to increase the reliability of estimates, and subjective methods help to assess innovativeness and the unique nature of an implemented idea.

Risk response measures are based on the data received in the course of assessment of key risks on the development and implementation phase. Timing risk management is affected by the task's location on the critical path, 
the excess of projected activities and availability of the project's time reserve.

Project's budget deficit risk is mitigated mainly through the mechanism of risk financing by way of establishment of a reserve in the amount of projected losses. In case of insufficient equity, the innovator may insure the risk or raise financing in case of risk realization.

Therefore, the result represents an integrated methodological approach to management of key risks on development and implementation phases, which is realized through identification of specific project risks affecting the key parameters of the project, assessment of potential adverse effect of these risks and determination of efficient risk response measures.

\section{Discussion}

The task of innovative projects risks management is one of the most difficult in project management due to such a specific peculiarity of innovations as high degree of uncertainty in respect of the future result of their realization. Depending on the phase of the innovation's life cycle, the parameters of innovative projects risk management change, which, in turn, results in the need to use various methodological tools.

Obtaining of information about probabilities of a random event is the main task in quantitative assessment of innovative project risk. The probability of event occurrence may be determined by using objective or subjective methods. The objective method is based on the estimated frequency of occurrence of such event. The subjective method is based on the use of subjective criteria (estimator's judgment and personal experience), and in this case the probability of event may be different when assessed by different experts.

Apart from traditional understanding of risk as an objective or subjective probability, there is also another approach to creation of the mathematical model of risk, which is the basis for formalization of quantitative assessment of innovative project risk. This is a fuzzy set approach to the project risk assessment. When uncertainty increases, classic probabilistic descriptions give way, on the one hand, to subjective probabilities based on expert assessments, and, on the other hand, to the probabilities determined qualitatively rather than quantitatively. Pointwise estimates of probability distributions are replaced by interval (for expert methods) and triangle fuzzy estimates (for fuzzy sets theory methods). This raises the question of the degree of variation (increase or decrease) of uncertainty for the purpose of more adequate application of one or another method. It is clear that if statistical data (of subjective or objective nature) may be obtained, the best thing to do is to study statistics on the basis of probability models.

The following theoretical conditions are generally used for development of risk indicators:

- risk assessment is based on the random event's concept;

- the issue of obtaining information about possible events, probabilities of their occurrences, importance (significance degree) is highly important for risk assessment;

- $\quad$ any information usually contains measurement errors, which affect the reliability of assessment;

- decisions made under the conditions of uncertainty determine the complexity of the issue of risk's quantitative assessment.

Therefore, obtaining of information about probabilities of a random event is the main task in quantitative assessment of innovative project's risk. When uncertainty reaches critical values, when there are no quantitative data on subjective probabilities, or when only qualitative estimates prevail, application of subjective probabilistic methods becomes really limited. At the same time, the fuzzy set approach to creation of the mathematical model of innovative project risk assessment allows to take into account the uncertainty of using the fuzzy logic method. Fuzzy logic elements may be introduced by the transition from classic probabilistic distributions to probabilistic distributions with fuzzy parameters or by introduction of linguistic variables.

Internal and external (in relation to the project) reasons and their sources may act as the project's risk factors. That's why the factors are called internal and external. The first step in the solution of a risk assessment task lies in identification of a combination of factors which may significantly affect implementation of an innovative project, as well as in taking protective measures against the influence of adverse factors. According to international classification, project risk is called as a single risk, if it is considered independently, with no relation to other projects.

Currently, there is no uniform classification of innovative project risk factors. Each innovative project is unique; therefore, the arguments made by some authors regarding impossibility of creation of a universal uniform classification of risks make some sense. It is far more important to determine the individual list of risks and their factors, which are potentially dangerous for the innovative project, and to assess them. On the other hand, despite the individual and unique nature of each innovative project, there is admittedly a certain list of factors which (with some certainty) may be applied to all innovative projects according to the system of limitations and assumptions intrinsic to innovative project development. 
This hypothesis requires verification and proofs. Substantiation of such classification allows to launch formalization of innovative project risk assessment, and such substantiation is the basis of qualitative assessment of innovative project risk, allowing to shift to quantitative assessment of innovative project risk.

Methods of quantitative assessment of risk apply such values as possible yields and relevant probabilities of innovative project risk factors. These data need to be obtained somehow. There are two approaches to obtaining of such data: subjective (expert) and objective (on the basis of statistics). Each of the above methods is not applied in its pure form, since projections on the basis of any data should always take into account possible change in situation, i.e. include the elements of expert estimates.

Advantages of the elaborated algorithm of innovative project risk management on the phases of innovation's development and implementation, as compared with the ones described in academic literature, are as follows:

- it implies consistent systematic implementation of risk management phases and matching of assessment results with risk treatment measures: projections of the timeframe and financial resources allow to determine the most risky tasks/items, and, on the basis of quantitative values, to take steps towards mitigation of the impact on specific project risks with respect to the determined tasks. Estimation of time losses allows to determine a time reserve for protection of the project completion date, and estimation of probable budget fluctuations - to form a reserve for the tasks, which are the most exposed to risks;

- it takes into account the key and specific risks intrinsic to the phases of innovative project development and implementation;

- it operates a set of risks subject to quantitative measurement and assessment: the timing risk and project budget deficit risk;

- it includes the minimum required (though sufficient for successful risk management) set of correlating assessment methods with the purpose of reduction of efforts required for the estimates and receipt of reliable results;

- it is based on the study of subjective axiological probabilities rather than beta distribution, which allows to estimate the statistical non-homogeneity of risk probabilities and innovativeness of the studied projects;

- it allows to determine possible time and resource losses in a consistent and multiple-option manner;

- $\quad$ when reserving funds in terms of the tasks, such approach allows to release money for fulfillment of project tasks (phases).

\section{Conclusion}

In accordance with the tasks, the result of the research is represented by the algorithm of innovative project risk management on development and implementation phases. Such algorithm implies consecutive systematic implementation of management phases and matching of assessment results with risk treatment measures.

The developed algorithm allows to manage (in a comprehensive manner) the key and specific risks of innovative projects implementation and mitigate the defects identified in the course of study of innovation risk management methods described in modern academic literature.

The developed risk management algorithm operates the parameters, which are uniform in project planning; it may be adapted to any project which emphasizes its universal nature. Moreover, this approach may be applied to different areas of innovations.

The developed risk management algorithm may be supplemented with management models in respect of the risk of practical non-realizability of an innovative idea and the risk of failure to achieve the planned functional characteristics of innovation, which are less subject to quantitative measurement, as well as with the algorithms of risk management on other phases of the innovative project - the phases of idea generation and innovation commercialization, which require serious consideration of the specific nature of the innovative entrepreneurship.

The results of this study may be used for development of application software (in the form of an independent software product or in the form of an automated system module), which would realize a set of algorithms of innovative project risk management on various phases of the innovation's life cycle.

\section{Acknowledgements}

This research project was supported by the Russian Scientific Fund (RSF Project No. 14-18-00519). 


\section{References}

Allen, Fr., \& Gale, D. (1994). Financial innovation and risk sharing. Cambridge (Mass.); L.: MIT.

Balabanov, I.T. (1996). Risk-menedzhment [Risk management]. Moscow: Finance and statistics [In Russian].

Batkovskiy, A.M., Konovalova, A.V., \& Fomina, A.V. (2014). Ocenka riskov realizacii innovacionnyh proektov v radiojelektronnoj promyshlennosti [Risk assessment of innovative projects in the radio-electronic industry] Voprosy radiojelektroniki. Serija "Radiolokacionaja tehnika" - Radio electronics questions. Radiolocation Equipment series, 3, 168-182 [In Russian].

Bernstein, P.L. (1996). The New Religion of Risk Management. Harvard Business Review, Volume 74, March/April, 47-51.

Bowers, J., \& Khorakian, A. (2014). Integrating risk management in the innovative project // European Journal of Innovation Management, Volume 17, Issue 1, 2014, 25-40. http://dx.doi.org/10.1108/EJIM-01-2013-0010

Demkin, I.V. (2005a). Ocenka riska innovacionno-investicionnyh proektov na osnove imitacionnogo stohasticheskogo modelirovanija [Risk assessment of innovative and investment projects on the basis of imitating stochastic modeling]. VJeO-VEO, 249-273 [In Russian].

Demkin, I.V. (2005b). Ocenka integrirovannogo innovacionnogo riska na osnove metodologii Value At Risk [Integrated innovative risk assessment on the basis of methodology of Value At Risk]. Problemy analiza riska - Analysis Problems, 3, 4, 362-378 [In Russian].

Elahi, E. (2013) Risk management: The next source of competitive advantage // Foresight, Volume 15, Issue 2, April 2013, 117-131. http://dx.doi.org/10.1108/14636681311321121

Eliyahu, M. Goldratt. (1997). Critical Chain. Publisher: North River Press.

Fathutdinov, R.A. (2003). Innovacionnyj menedzhment [Innovative management]. Saint Petersburg: Piter [In Russian].

Fishbern, P. (1978). Teorija poleznosti dlja prinjatija reshenij [Usefulness theory of for decision-making]. Moscow: Nauka [In Russian].

Gracheva, M.V., \& Ljapina, S.V. (2010). Upravlenie riskami v innovacionnoj dejatel'nosti [Risk management in innovative activity]. Moscow: JuNITI-DANA [In Russian].

Ivanov, A.A., Olejnikov, S.Ja., \& Bocharov, S.A. (2008). Risk-menedzhment [Risk management]. Moscow: EAOI publishing center [In Russian].

Johnstone-Bryden, I.M. (1996). Managing Risk: How to work succesfully with risk. London: AVEBURY.

Kaplan, S. (1997).The world of risk analysis. Risk analysis, Volume 17, Issue 1, 407-417.

Karzhaev, A.T. (2006). Innovacionnye riski venchurnogo kapitala i upravlenie imi [Innovative risks of the venture capital and risk management]. Moscow: Economics [In Russian].

Klimenko, O. Metod kriticheskoj cepi: jeffektivnoe upravlenie proektami s ispol'zovaniem buferov vremeni i resursov [Critical chain method: effective project management with buffers of time and resources]. URL: http://www.iteam.ru/publications/project/section 35/article_3448/ [In Russian].

Kulikovā, E.E. (2008). Risk-menedzhment: innovacionnyj aspect [Risk management: innovative aspect]. Moscow: Berator-Publishing [In Russian].

Marle, F., \& Gidel, T. (2015). Assisting project risk management method selection // International Journal of Project Organisation and Management, Volume 6, Issue 3, 2015, 254-282. http://dx.doi.org/10.1504/IJPOM.2014.065255

Nedosekin, A.O., \& Abdulaeva, Z.I. (2010) Upravlenie korporativnymi riskami i shansami [Corporate risks and chances management]. Saint Petersburg: "Saint Petersburg" [In Russian].

Olsson, N.O.E., \& Spjelkavik, I. (2015). Assumption surfacing and monitoring as a tool in project risk management // International Journal of Project Organisation and Management, Volume 6, Issue 1-2, 2015, 179-196. http://dx.doi.org/10.1504/IJPOM.2014.059740

Popov, V.L. (2009). Upravlenie innovacionnymi proektami [Innovative project management]. Moscow: INFRA-M [In Russian].

Samovoleva, S.A. (2008). Analiz riskov innovacionnyh proektov. [Risk analysis of innovative projects] Innovacionnaja politika i problemy razvitija nacional'noj innovacionnoj sistemy - Innovative policy and problems of national innovative system development, 227-235 [In Russian].

Shapira, Z. (1995). Risk taking: a managerial perspective. New York: Russel Sage Foundation.

Shirjaev, A.N. (1989). Verojatnost' [Probability]. Moscow: Nauka [In Russian].

Taplin, R. (ed.) (2005). Risk Management and Innovation in Japan, Britain and the USA. Routledge.

Valdajcev, S.V. (2001). Upravlenie innovacionnym biznesom [Innovative business management]. Moscow: JuNITI-DANA [In Russian].

Valdajcev, S.V. (1997). Ocenka biznesa i innovacii [Business and innovation assessment]. Moscow: Filin [In Russian].

Vertakova, Ju.V., \& Simonenko, E.S. (2008). Upravlenie innovacijami: teorija i praktika [Innovation management: theory and practice]. Moscow: Exmo [In Russian]. 